\title{
Sarcoptes mite epidemiology and treatment in African buffalo (Syncerus caffer) calves captured for translocation from the Kafue game management area to game ranches
}

\author{
Hetron M Munang'andu*1,3, Victor M Siamudaala2, Wigganson Matandiko², Musso Munyeme³, \\ Mwelwa Chembensofu ${ }^{3}$ and Enala Mwase ${ }^{3}$
}

\begin{abstract}
Background: In Zambia, translocation of wildlife from National Parks to private owned game ranches demands that only animals free of infectious diseases that could adversely affect the expansion of the wildlife industry should be translocated to game ranches. Sarcoptes mange (Sarcoptes scarbiei) has been involved in the reduction of wildlife populations in some species.
\end{abstract}

Results: Sarcoptes mange (Sarcoptes scarbiei) was detected and eradicated from two herds of African buffalo (Syncerus caffer) calves captured in the Kafue GMA in July 2004 and August 2005. The overall prevalence was estimated at 89.5\% (77/86). Sex had no influence on the occurrence and severity of the disease. Of the 86 calves used in the study, $72.1 \%$ had good body condition scores, $20.9 \%$ were fair and $7.0 \%$ were poor. Of the 77 infected calves, $53.2 \%$ were mildly infected, $28.6 \%$ were moderately and $18.2 \%$ were severely infected. Body condition score was correlated to the severity of the infection ( $r=0.72, p<0.000, n=86$ ) at capture. Eradication of Sarcoptes mites from the entire herd using ivermetcin was dependant on the severity of the infection. The overall ability of ivermectin to clear the infection after the first treatment was estimated at $81.8 \%(n=77)$. It increased to $94.8 \%$ and $100 \%$ after the second and third treatments respectively.

Conclusion: This is the first report on the epidemiology and treatment of Sarcoptes mange in African buffaloes in Zambia. This study improves our understanding about Sarcoptes scabiei epidemiology and treatment which will have further applications for the safe animal translocation.

\section{Background}

Sarcoptic mange is a highly contagious disease affecting humans [1,2], domestic animals [3] and wildlife [4]. The disease is caused by Sarcoptes scabiei mites that burrow in the epidermis of the skin where they form tunnels and deposit their eggs and digestive secretions causing intense skin irritations. The mites complete their lifecycle within a few weeks giving rise to high densities reaching up to $5000 \mathrm{mites} / \mathrm{cm}^{2}$ in some species [5]. This leads to alopecia and hyperkeratosis of the skin [6]. The disease

* Correspondence: HetronMweemba.Munang'andu@veths.no 1 Department of Basic Sciences and Aquatic Medicine, Section of Aquatic Medicine and Nutrition, Norwegian School of Veterinary Sciences, Ullevålsveien 72, P. O. Box 8146 Dep, NO-0033 Oslo, Norway Full list of author information is available at the end of the article has been associated with high morbidity and mortality leading to population reductions in some species [7-10]. The efficacy of ivermectin in the treatment of Sarcoptes mange in different wildlife species has been carried out with variable responses [11-14]. Although the disease affects various wildlife species $[15,15]$, there are few reports describing its epidemiology in African game. In Zambia, it has been reported in humans and domestic animals with limited reports on wildlife [16].

The expansion of the game ranching industry in Zambia as an ex-situ conservation strategy has led to the translocation of several wildlife species from state owned National Parks (NPs) and game management areas (GMAs) to private owned game ranches in recent years. 
However, infectious diseases such as foot and mouth disease, Sarcoptes mange and bovine tuberculosis are a major constraint to the translocation of wildlife [17] because regulations demand that only animals not infected with such infectious diseases should be translocated to game ranches. This paper discusses the clinical observations made and the treatment regime used to eradicate sarcoptic mange from the entire herd of buffalo calves captured in the Kafue GMA prior to translocation.

\section{Methods}

\section{Animal data}

The Study Was Carried Out At Nanzhila $\left(26^{\circ} 03^{\prime} E\right.$, $15^{\circ} 44^{\prime} \mathrm{S}$ ) located on the western end of the Kafue flats GMA which is a wetland area designated as Ramsar Site No. 530 [18]. The area supports a transhumance grazing system for the traditional livestock farmers from the surrounding upland areas by providing grazing pastures for cattle in the dry season. GMAs are considered to be buffer zones being located between NPs and communal lands and are also referred to as livestock/wildlife interface areas because the co-existence of domestic animals and wildlife is permitted in these areas [19]. In August 2004 a total of 48 African buffalo calves were captured and used in the study while 38 were used in July 2005 with permission of the Zambia wildlife Authority (ZAWA) who are the custodians of wildlife in Zambia (Project authorization ref: 006/68-07-05). Age was estimated at four to six months for all calves using tooth development [20]. The calves were kept in quarantine facilities for 90 days and were sampled at 30 days intervals. At every sampling, calves were immobilized using M99 (etorphine hydrochloride, Novartis Ltd., Animal Health, South Africa) and reversed using M5050 revivon (dreprenorphine, Novartis SA Ltd., Animal Health, South Africa).

\section{Sarcoptes diagnosis and treatment}

The severity of the disease was classified into three categories as mild $(+)$, moderate $(++)$ and severe $(+++)$ as described by Pence et al [21]. The mild group involved calves with focal lesions covering small patches of the body surface. Most of the lesions observed in this group were in the initial phase and they included erythema, pruritis, encrustations, suppuration and alopecia. The most affected body parts were the forehead, shoulders, hump and hock joints. The moderate group involved animals with actively progressing lesions covering large areas extending to almost half of the body surface. There were large surfaces of erythema, pruritis, alopecia, scabs, parakeratosis and fissures on some of the animals. Suffice to mention that some of the lesions observed in this group were similar to those observed in the mild group only that in the moderate group lesions were progressive and diffuse covering large areas. Severe groups were ani- mals whose lesions covered more than half of the body surface. Alopecia, parakeratosis, thick and wrinkled skin surfaces were more pronounced in this group than in the mild and moderate groups. Body condition score was recorded as good $(++)$, fair $(+)$ or poor $(-)$ depending on the degree of emaciation and skin pliability. Highly emaciated animals having little muscle with no sign of fat deposits and the skin falling slowly or staying in a fold after pulling a portion on the neck were scored poor (-). Animals having moderate deposition of muscle with the skin of the neck folding moderately faster than those in poor body conditions were scored as fair $(+)$ while animals with excess fat and muscle with the skin quickly falling to its original position after the pliability test were scored as good $(++)$.

Skin scrapings were collected at every sampling. All claves were treated with $200 \mu \mathrm{g} \mathrm{kg}^{-1}$ ivermectin (Novartis SA Ltd., Animal Health) at each sampling time point irrespective of whether they had mites detected or not. They were translocated to game ranches within three days after being declared free of mites after the fourth screening test.

At the School of Veterinary Medicine at the University of Zambia, skin scrapings were examined after treatment with $20 \%$ potassium hydroxide [22]. Identification of mites was carried out as described elsewhere [23]. Sex, age, body condition score, severity score of the clinical condition and laboratory results for each calf were recorded in Exel sheets at each sampling time point. Data was analyzed using STATA SE/10 for windows (Stata Corp. College Station, TX, USA, http://www.stata.com). Chi-square was used to test the measures of association between sex and occurrence of the disease while the Pearson's correlation coefficient test was used to measure the correlation between severity of the disease and body condition score.

\section{Results}

\section{Sarcoptes mite epidemiology}

Sex ratio (male:female) was estimated at 1:12. Our observations indicate that sex had no influence on the occurrence $\left(x^{2}=0.093, p>0.70\right)$ and severity $\left(x^{2}=0.70, p>\right.$ 0.70 ) of the disease. Overall prevalence for the two herds was estimated at $89.5 \%(77 / 86)$ at capture (Table 1$)$. Of the 86 calves used in the study, $72.1 \%$ had good body condition score, $20.9 \%$ were fair and $6.9 \%$ were poor at capture (Table 2). Of the 77 infected calves, $53.2 \%$ were mildly infected, $28.6 \%$ were moderately and $18.2 \%$ were severely infected at capture. Body condition score was positively correlated to the severity of the infection $(\mathrm{r}=$ $0.72, \mathrm{p}<0.000, n=86$ ) at capture.

\section{Sarcoptes mite treatment}

Decrease in the number of infected calves after the first treatment was related to the severity of the infection 
Table 1: Treatment regime and detection of mites at different sampling time points.

\begin{tabular}{ccccccc}
\hline \multirow{2}{*}{ Year } & & & \multicolumn{2}{c}{ Number of calves detected with presence of Sarcoptes scabiei } \\
mites at;
\end{tabular}

*Number of calves infected with Sarcoptes mange at capture (first sampling).

observed at capture (Table 1). Of the 41 mildly infected calves, only two had Sarcoptes mites after the first treatment $(4.98 \%)$ while in the moderately affected group $45.45 \%(10 / 22)$ needed a second treatment for the mites to be eliminated. In the severely affected group, there was a gradual decline with $28.57 \%(4 / 14)$ not having mites after the first treatment, $42.86 \%(10 / 14)$ after the second treatment and another $28.57 \%$ (4/14) after the third treatment. The overall drug ability to clear the infection was estimated at $81.8 \%(n=77)$ after the first treatment. It increased to $94.8 \%$ after the second treatment and reached $100 \%$ after the third treatment. The calves were translocated to game ranches within three days after the fourth treatment after they were declared free of Sarcoptes mange.

\section{Discussion}

In Zambia, sarcoptic mange has been reported in sitatunga (Tragelaphus spekii), hartebeest (Alcephelus lichtensteini) and silver-backed-jackal (Canis mesomelas) in wildlife [16]. In domestic animals the disease has been reported in cattle, goats and pigs [16]. It has not been reported from the African buffalo and no comprehensive study has been carried out describing the clinical findings in wildlife in Zambia. In line with observations made by Pence and Ueckermann [24], our findings indicate that clinical conditions vary between animals depending on the severity of the infection. Tikaram and Ruprah [25] observed that the incidence of sarcoptic mange was highest in young animals below one year. They noted that prevalence decreased with advancement of age and that

Table 2: Body condition score of the calves at different sampling time points.

\begin{tabular}{|c|c|c|c|c|c|c|c|}
\hline \multirow{3}{*}{ Year } & \multirow{3}{*}{$n$} & \multirow{3}{*}{ Category } & \multirow{3}{*}{ Score } & \multicolumn{4}{|c|}{ Body score condition at different sampling time points } \\
\hline & & & & Day 1 & Day 30 & Day 60 & Day 90 \\
\hline & & & & Number of calves & Number of calves & Number of calves & Number of calves \\
\hline \multirow[t]{3}{*}{2004} & 48 & Good & ++ & 35 & 47 & 48 & 48 \\
\hline & & Fair & + & 11 & 1 & - & - \\
\hline & & Poor & - & 2 & - & - & - \\
\hline \multirow[t]{3}{*}{2005} & 38 & Good & ++ & 27 & 36 & 38 & 38 \\
\hline & & Fair & + & 7 & 2 & - & - \\
\hline & & Poor & - & 4 & - & - & - \\
\hline Totals & 86 & & & 86 & 86 & 86 & 86 \\
\hline
\end{tabular}


sex had no influence on the incidence of the disease [25]. The high prevalence $89.5 \%(77 / 86)$ obtained in the present study could be attributed to the fact that the animals involved were young ranging between four and six months of age at capture. We also observed that sex had no influence on the occurrence of the disease in the calves.

Fain et al [26] postulated that Sarcoptes mange originated as a human parasite that spread to domestic animals and subsequently transmitted to various wildlife species by contact with their domestic counterparts. It is not known how Sarcoptes scabiei was introduced in buffalo herds in the Kafue GMA although the disease has been present in domestic animals in the area [16]. Studies have shown that the transmission of mange was density dependant being more prevalent during times of higher environmental stress such as drought $[27,28]$. In the present study, the high prevalence of Sarcoptes mange (89.5\%, $n=86$ ) reported in the calves could have been exacerbated by stress factors caused by the scarcity of water and grazing pastures during the dry season in the months of May to October on the Kafue flats. Livestock owners in the upland areas surrounding the Kafue flats practice a transhumance grazing system by moving their animals into the flats during the dry season leading to the sharing of grazing pastures and water between wildlife and livestock. This impacts a high population density on the flats. It is likely that Sarcoptes mange could have been transmitted from livestock to wildlife during such contacts. However, to fully understand the factors responsible for the epidemiology and transmission of the disease between species in the Kafue flats it is imperative that wildlife and livestock surveys be synchronized involving molecular studies of the gene flow of this parasite between different host species and geographical localities [29]. Perez et al [30] observed that Sarcoptes mange cases were higher in the cold season reducing in the hot months in summer when conditions were unfavorable for the survival of the mites. In Zambia, the cold season is in the months of June to August and this could have contributed to the increase in the number of calves infected given the timing of the present study that calves were captured in the cold months of August 2005 and July 2005. Treating the calves for the subsequent three months means that the treatment regime extended into the hot months of September to November which could have impacted negatively on the survival of the mites. It is likely that climatic factors had confounding effects on the treatment regime used in the current study. However, there is a need to carry out more detailed studies in order to determine the effect of climate on the epidemiology of sarcoptic mange on the Kafue basin.

The efficacy of ivermectin in the treatment of Sarcoptes mange in domestic animal has been studied by different scientists with some studies showing high responses after the first treatment [31,32] although other studies have shown a gradual decrease in the number of mites after multiple doses of ivermetcin administered at regular intervals [33]. In Wildlife, there have been variable responses on the treatment of Sarcoptes mange using ivermectin in different animal species. Leon-Vizcaino et al [34] managed to eliminate the Sarcoptes mites from Spanish ibex (Capra pyrenaica) in the early stages of the infection, although double injections with high doses of ivermectin did not yield success in chronically infected animals. However, Skerratt [35] reported a complete resolution of clinical signs in wombats (Wombatus ursinus) after three injections of ivermectin administered 10 days apart although mites were not completely eliminated until the wambots were given a second regime of treatment. Yeruham et al [36] reported of complete recovery of severely infected wild ruminants kept in zoological gardens after mutlitple treament using ivermectin administered orally at regular intervals. These observations indicate that Sarcoptes mites can be eliminated from wild animals kept in captivity using ivermectin. Besides, ivermectin has been shown to be an effective drug for treating various endoparasites and parasitic skin diseases [37]. In the present study, we observed a gradual decrease in the number of infected calves from the first to the third treatment (Table 1). Our observations indicate that eradication of Sarcoptes scabiei mites using ivermectin was dependant on the severity of the infection (Table 1) similar to observations made by Skerratt [35].

\section{Conclusion}

Sarcoptes mites were eradicated from African buffalo calves captured from the Kafue game management area after the third treatment indicating that it is possible to eradicate some infectious diseases from infected wildlife populations prior to translocation by using the screening and treatment method. Hence, the risk of introducing Sarcoptes mange to naïve wildlife populations on the game ranches was avoided. Suffice to mention that such disease eradication methods are expensive as they require frequent immobilization of animals. Prolonged keeping of wildlife in captivity imposes a lot of stress on the animals. Therefore, we recommend that highly potent drugs aimed at reducing the need for repeat treatments should be explored for use in wildlife medicine. In addition, disease control strategies involving less strenuous handling procedures should be used with a view of promoting the success of ex-situ conservation.

\section{Authors' contributions}

HMM and VS conceived the study, participated in designing, coordination and capture of the animals. They were instrumental in drafting the manuscript. WM and MM participated in the capture and sampling as well as in drafting the 
manuscript. MC and EM carried out the laboratory diagnosis. All authors read and approved the manuscript.

\section{Acknowledgements}

The authors would like to thank Chaminuka game reserve as well as Eureka and Tim Ashworth game ranches for financing the Project. The authors also thank the Zambia wildlife Authority (ZAWA) for providing the study animals and their permission to carry out the project in the Kafue Basin game management area.

\section{Author Details}

1 Department of Basic Sciences and Aquatic Medicine, Section of Aquatic Medicine and Nutrition, Norwegian School of Veterinary Sciences, Ullevålsveien 72, P. O. Box 8146 Dep, NO-0033 Oslo, Norway, 2Zambia Wildlife Authority, P. O. Box 830124, Chilanga, Zambia and ${ }^{3}$ School of Veterinary Medicine, University of Zambia, P.O. Box 32379, Lusaka, Zambia

Received: 3 March 2010 Accepted: 1 June 2010

Published: 1 June 2010

\section{References}

1. Skerratt LF, Beveridge I: Human scabies of wombat origin. Aust Vet $J$ 1999, 77:607.

2. Terry BC, Kanjah F, Sahr F, Kortequee S, Dukulay I, Gbakima AA: Sarcoptes scabiei infestation among children in a displacement camp in Sierra Leone. Public Health 2001, 115:208-11.

3. Soll MD, Carmichael IH, Swan GE, Scherer H: Control of cattle mange in southern Africa using ivermectin. Trop Anim Health Prod 1987 19:93-102.

4. Pence DB, Ueckermann E: Sarcoptic mange in wildlife. Rev Sci Tech 2002, 21:385-98.

5. Bornstein S, Mörner T, Samuel WM: Sarcoptes scabiei and sarcoptic mange. In Parasitic Diseases of Wild Mammals Edited by: Samuel WM, Pybus MJ, Kocan AA. Manson Publishing, London, UK; 2001:107-19.

6. Newman TJ, Baker PJ, Harris S: Nutritional condition and survival of red foxes with sarcoptic mange. Can. J. Zool 2002, 80:154-61.

7. Lindström ER: Pattern and spread and effects of sarcoptic mange among red fox populations in Sweden. In Global Trends in Wildlife Management Edited by: Bobek B, Perzanowski K, Regelin WL. Swiat Press, Krakow-Warszawa, Poland; 1991:591-5.

8. Morner T: Sarcoptic mange in Swedish wildlife. Rev Sci Tech 1992, 11:1115-21.

9. Soulsbury CD, lossa G, Baker PJ, Cole NC, Funk SM, Harris S: The impact of sarcoptic mange Sarcoptes scabiei on the British fox Vulpes vulpes population. Mammal Rev 2007, 37:278-96.

10. Gonzalez-Candela M, Leon-Vizcaino L, Cubero-Pablo MJ: Population effects of sarcoptic mange in Barbary sheep (Ammotragus lervia) from Sierra Espuna Regional Park, Spain. J Wildl Dis 2004, 40:456-65.

11. Leon-Vizcaino L, Cubero MJ, Gonzalez-Capitel E, Simón MA, Pérez L, Rocío Ruiz deYbáñez M, Ortíz JM, González Candela M, Alonso F: Experimental ivermectin treatment of sarcoptic mange and establishment of a mange-free population of Spanish ibex. J WildI Dis 2001, 37:775-85.

12. Skerratt LF: Clinical response of captive common wombats (Vombatus ursinus) infected with Sarcoptes scabiei var. wombati. J WildI Dis 2003, 39:179-92.

13. Twomey DF, Birch ES, Schock A: Outbreak of sarcoptic mange in alpacas (Vicugna pacos) and control with repeated subcutaneous ivermectin injections. Vet Parasitol 2009, 159:186-91.

14. Yeruham I, Rosen S, Hadani A, Nyska A: Sarcoptic mange in wild ruminants in zoological gardens in Israel. JWildI Dis 1996, 32:57-61.

15. Pence DB, Ueckermann E: Sarcoptic mange in wildlife. Rev Sci Tech 2002, 21:385-98.

16. Mwase ET, Baker AS: An annotated checklist of mites (Arachnida: Acari) of Zambia. Zootaxa 2006, 1106:1-24.

17. Munang'andu HM, Siamudaala VM, Nambota A, Bwalya JM, Munyeme M, Mweene AS, Takada A, Kida H: Disease constraints for utilization of the African buffalo (Syncerus caffer) on game ranches in Zambia. Jpn J Vet Res 2006, 54:3-13.

18. RIS: The Annotated Ramsar List: Zambia. The Ramsar Convention on Wetlands. Ramsar Convention Secretariat, Rue Mauverney 28, CH-1196 Gland,
Switzerland. 1 [http://www.ramsar.org/cda/en/ramsar-pubs-annolistannotated-ramsar-15789/main/ramsar/130-168\%5E9 40000 ].

19. Balakrishna M, Ndhlovu D: Wildlife utilization and local people; A case study in Upper Lupande game management area, Zambia. Environ cons 1992, 19:135-44.

20. Grimsdell JJR: Age determination of the African buffalo, Syncerus caffer sparrman. EAfr Wildlife J 1973, 11:54.

21. Pence DB, Windberg LA, Pence BC, Sprowls R: The epizootiology and pathology of sarcoptic mange in coyotes, Canis latrans, from south Texas. J Parasitol 1983, 69:1100-15.

22. Alasaad S, Rossi L, Soriquer RC, Rambozzi L, Soglia D, Pérez JM, Zhu XQ: Sarcoptes mite from collection to DNA extraction: the lost realm of the neglected parasite. Parasitol Res 2009, 104:723-32.

23. Bowman DD: Georgis' Parasitology for Veterinarians. 6th edition. Saunders. W.B. Saunders Co., Philadelphia, USA; 1995.

24. Pence DB, Ueckermann E: Sarcoptic mange in wildlife. Rev Sci Tech 2002, 21:385-98.

25. Tikaram SM, Ruprah NS: Incidence of sarcoptic mange in buffaloes in India. Trop Anim Health Prod 1968, 18:86-90.

26. Fain A: Epidemiological problems of scabies. Int J Dermatol 1978, 17:20-30.

27. Skerratt LF, Martin RW, Handasyde KA: Sarcoptic mange in wombats. Aust Vet J 1998, 76:408-10.

28. Walton SF, McBroom J, Mathews JD, Kemp DJ, Currie BJ: Crusted scabies: A molecular analysis of Sarcoptes scabiei variety hominis populations from patients with repeated infestations. Clin Infect Dis 1999, 29:1226-30

29. Rasero R, Rossi L, Maione S, Sacchi P, Rambozzi L, Sartore S, Soriguer R, Spalenza V, Alasaad S: Host taxon-derived Sarcoptes mites in European wildlife animals, revealed by microsetellite markers. Biol cons 2010, 143:1269-77.

30. Perez JM, RuizMartinez I, Granados JE, Soriguer C, Fandos P: The dynmamic of sarcoptic mange in ibex of Sierra Nevada in Spain Influence of climatic factors. J Wild Res 1997, 2:86-9.

31. Gill BS, Singh J, Gill BS, Singh A, Khehra SS, Rai A, Hussain O: Efficacy of ivermectin against mange and gastrointestinal nematodes of buffalo (Bubalus bubalis). Vet Parasitol 1989, 31:141-7.

32. Rossi L, Rambozzi L, Ferroglio E: Diagnosi e monitoraggio della rogna sarcoptica nelsuino. Pfizer Animal health Proceedings 1998, 18:3-15.

33. Mitra J, Bardhan G, Basu A: Efficacy of oral ivermectin against sarcoptic mange in buffalo calves. Indian Vet J 2005, 82:666-7.

34. Leon-Vizcaino L, Cubero MJ, Gonzalez-Capitel E, Simón MA, Pérez L, Rocío Ruiz deYbáñez M, Ortíz JM, González Candela M, Alonso F: Experimental ivermectin treatment of sarcoptic mange and establishment of a mange-free population of Spanish ibex. J WildI Dis 2001, 37:775-85.

35. Skerratt LF: Clinical response of captive common wombats (Vombatus ursinus) infected with Sarcoptes scabiei var. wombati. J Wildl Dis 2003, 39:179-92.

36. Yeruham I, Rosen S, Hadani A, Nyska A: Sarcoptic mange in wild ruminants in zoological gardens in Israel. JWildl Dis 1996, 32:57-61.

37. Heukelbach J, Winter B, Wilcke T, Muehlen M, Albrecht S, de Oliveira FA, Kerr-Pontes LR, Liesenfeld O, Feldmeier H: Selective mass treatment with ivermectin to control intestinal helminthiases and parasitic skin diseases in a severely affected population. Bull World Health Organ 2004, 82:563-71.

\section{doi: 10.1186/1746-6148-6-29}

Cite this article as: Munang'andu et al., Sarcoptes mite epidemiology and treatment in African buffalo (Syncerus caffer) calves captured for translocation from the Kafue game management area to game ranches BMC Veterinary Research 2010, 6:29 